\title{
STATUS TEKNOLOGI PENANGKAPAN TOGO DALAM PERSPEKTIF PERIKANAN BERTANGGUNG JAWAB DI DESA CEMARA LABAT
}

\section{STATUS ON RESPONSIBLE FISHERIES PERSPECTIVE OF TOGO FISHERIES AT CEMARA LABAT VILLAGE}

\author{
Febrina Berlianti $^{1}$, Roza Yusfiandayani ${ }^{2}$, M. Fedi A. Sondita ${ }^{2}$, Bambang Murdiyanto ${ }^{2}$ \\ ${ }^{1}$ World Wide Fund \\ ${ }^{2}$ Departemen Pemanfaatan Sumberdaya Perikanan, \\ Fakultas Perikanan dan Ilmu Kelautan, Institut Pertanian Bogor \\ Korespondensi: febrinaberlianti@gmail.com,ochaipb@gmail.com, fsondita@indo.net.id, \\ murdiyanto2001@yahoo.com
}

\begin{abstract}
Togo fishery in Cemara Labat Village covers fishing activities in river and ponds. Assessment on the status of fishing responsibility is one of initial steps in determining a strategy to develop sustainable fisheries. This study applied an assessment on two types of togo were analyzed by applying multi criteria analysis using the 13 criteria of responsible fishing. This study aims to determine the status of togo fishing technology and strategies to develop sustainable fisheries at the Cemara Labat Village. Based on status of fishing technology, both togo were considered good with same score 33, one indicator with bad category (score 1) and four indicators with good category (score 2). Both gear had the lowest score (score 1) on indicator of ensure the survival of fish and aquatic biota are returned to the waters (X10) and score 2 for fishermen competence indicator (X1). Other indicators in river with good category (score 2) were safety on the water (X2), regulatory compliance (X3) and fuel consumption of ships (X4) while for togo operated in ponds were the proportion of the catch (X9), potential damage to aquatic environments and habitats (X12) and potential conflicts (X13). Strategies to developed sustainable fisheries were emphasized the socio-economic characteristics and behavior of fishermen through socialization and silvofisheries development on togo fisheries in ponds.
\end{abstract}

Keyword: togo, river, ponds, responsibility

\begin{abstract}
ABSTRAK
Kegiatan perikanan togo di Desa Cemara Labat terdiri dari penangkapan di sungai dan tambak. Penilaian status teknologi penangkapan ikan merupakan salah upaya untuk mendukung pengelolaan perikanan togo yang lebih baik. Penilaian tentang tingkat tanggung jawab dua jenis togo dilakukan dengan menerapkan multi criteria analysis yang menggunakan 13 kriteria unit penangkapan ikan yang bertanggung jawab. Penelitian ini bertujuan menentukan status teknologi penangkapan togo dan menentukan strategi perbaikan perikanan tangkap di Desa Cemara Labat. Berdasarkan status teknologi penangkapan ikan, kedua jenis togo tergolong baik dengan memiliki skor yang sama yaitu 33 dengan masing-masing satu indikator bernilai buruk (skor 1) dan empat indikator bernilai cukup baik (skor 2). Kedua togo tergolong buruk (skor 1) pada indikator menjamin survival dari ikan dan biota perairan yang dikembalikan di sungai (X10) dan cukup baik (skor 2) pada indikator kompetensi nelayan (X1). Indikator yang berstatus cukup baik (skor 2) lainnya pada unit penangkapan togo yang dioperasikan di sungai yaitu keselamatan di sungai (X2), kepatuhan terhadap peraturan (X3) dan konsumsi bahan bakar kapal (X4), sedangkan untuk togo yang dioperasikan di tambak yaitu indikator proporsi hasil tangkapan yang dimanfaatkan(X9), potensi terjadi kerusakan lingkungan perairan dan habitat (X12) dan kejadian atau potensi konflik (X13). Strategi perbaikan perikanan tangkap antara lain melalui penekanan pada karakteristik dan perilaku sosial ekonomi nelayan melalui sosialisasi dan pengembangan silvofishery pada perikanan tangkap togo di tambak.
\end{abstract}

Kata kunci: bertanggung jawab, sungai, togo, tambak 


\section{PENDAHULUAN}

\section{Latar belakang}

Desa Cemara Labat yang terletak di Kabupaten Kapuas, Kalimantan Tengah merupakan daerah pengguna togo yang memiliki dua lokasi penangkapan (fishing area), yaitu di sungai dan di tambak. Togo merupakan alat tangkap bersifat pasif yang diklasifikasikan ke dalam kelompok perangkap dan penghadang (trap and guiding barrier). Sungai di Desa Cemara Labat merupakan bagian yang tak dapat terpisahkan dan merupakan salah satu lokasi penangkapan yang memberikan kontribusi terbesar pada sektor perikanan terutama perikanan udang. Seiring dengan perkembangan waktu, maka sebagian nelayan memanfaatkan lahan mangrove yang dilintasi oleh Sungai Cemara Labat menjadi tambak sebagai lokasi penangkapan togo dengan kontruksi yang lebih sederhana. Tambak berfungsi sebagai tempat yang dimanipulasi oleh nelayan agar udang bisa masuk sehingga nelayan dapat menangkap dengan lebih mudah.

Tambak yang dibangun sejak tahun 2005 ini mulai mengalami peningkatan yang mengakibatkan pada meningkatnya kegiatan penangkapan udang terhitung sejak empat tahun terakhir. Peningkatan kegiatan penangkapan udang juga diiringi dengan perluasan lahan tambak dari 50 ha menjadi 300 ha atau setara dengan kira-kira 60 nelayan, sementara jumlah nelayan di sungai sendiri mengalami sedikit penurunan menjadi 20 orang.

Meskipun suatu alat penangkapan ikan tampak sederhana, jika dioperasikan secara berlebihan, dapat mengancam kelestarian sumberdaya ikan target. Penggunaan alat tangkap ikan dalam pemanfaatan sumber daya ikan harus benar-benar memperhatikan kesetimbangan dan meminimalkan dampak negatif bagi kehidupan biota lain.

Menurut Brown et al. (1998), penangkapan ikan secara berlebihan dapat mengurangi keberlanjutan populasi sumber daya ikan. Selanjutnya, berkurangnya satu spesies secara drastis akan mengubah rantai makanan yang dapat mengganggu keseimbangan ekosistem perairan. Jika hal ini terjadi maka sumberdaya perikanan togo akan habis dan mengancam kelestarian ekologi serta ekosistem yang ada di wilayah tersebut yang kemudian berdampak pada pertumbuhan ekonomi. Oleh karena itu, penelitian ini akan mengkaji lebih jauh keberadaan perikanan togo di Desa Cemara Labat dalam mendukung pengembangan perikanan tangkap sekaligus menjaga keberlanjutan sumber daya ikan. Hal ini juga dilakukan mengingat dalam rangka mewujudkan perikanan tangkap yang berkelanjutan (sustainable fisheries capture) yang sesuai dengan ketentuan pelaksanaan perikanan bertanggung jawab (FAO Code of conduct for Responsible Fisheries/CCRF) maka eksploitasi sumberdaya hayati laut harus dapat dilakukan secara bertanggung jawab (responsible fisheries). Penilaian tentang tingkat tanggung jawab unit penangkapan togo dapat dilakukan dengan menerapkan pendekatan multi criteria analysis sebagai perangkat pengambil keputusan yang dikembangkan untuk masalah-masalah kompleks multikriteria dalam proses pengambilan keputusan (Mendoza dan Macoun 1999).

Topik penelitian ini sangat tepat karena sesuai dengan tren kebijakan pengembangan perikanan tangkap yang memprioritaskan penerapan teknologi penangkapan ikan yang bertanggung jawab untuk menjaga kelestarian sumberdaya ikan.Penelitian ini bertujuan untuk : Menentukan status teknologi penangkapan ikan togo yang diterapkan nelayan Desa Cemara Labat dari segi kriteria perikanan bertanggung jawab; Menentukan strategi perbaikan perikanan tangkap di Desa Cemara Labat berdasarkan status teknologi penangkapan ikan.

\section{METODE PENELITIAN}

Penelitian ini dilaksanakan selama pada bulan Agustus-September 2015. Pengambilan data dilakukan di tambak dan sungai Cemara Labat di Desa Cemara Labat, Kabupaten Kapuas, Kalimantan Tengah.

Alat yang digunakan dalam melakukan penelitian di lapangan adalah alat tulis, alat ukur berupa penggaris, meteran, timbangan serta peralatan dokumentasi seperti kamera, sedangkan bahan yang digunakan adalah kuesioner. Objek penelitian adalah togo yang dioperasikan di sungai dan tambak. 


\section{Unit penangkapan togo yang dioperasikan di Sungai}

Togo adalah alat tangkap bersifat pasif (Gambar 1). Alat tangkap ini berupa badan jaring berbentuk kerucut yang lenganlengannya diikatkan pada 2 tiang yaitu semakin melebar pada bagian ujung luar dan mengecil pada ujung di mana jaring togo ditempatkan. Togo yang dioperasikan di sungai Desa Cemara Labat ini sendiri merupakan modifikasi dari sungkur. Kontruksi togo di desa ini terdiri dari tiga bagian, yaitu sayap, badan dan kantong (buntut) di mana tiap bagian mempunyai ukuran yang berbeda yaitu sayap $4 \mathrm{~m} \times 6$ $\mathrm{m}$ (pxl), badan $6 \mathrm{mx} 4 \mathrm{~m}$ (pxl) dan kantong $4 \mathrm{~m} \times 2 \mathrm{~m}$ (pxl). Sayap dan badan togo yang digunakan terbuat dari bahan nylon dengan ukuran mata jaring (mesh size) $1 \mathrm{~cm}$. Kantong togo yang terbuat dari bahan nylon dilengkapi tali pengerut di bagian bawah kantong dengan ukuran mesh size pada bagian ini adalah $0.5 \mathrm{~cm}$. Bagian kantong memiliki ukuran mata jaring yang lebih kecil karena merupakan tempat hasil tangkapan ditampung.

Pelampung yang digunakan pada alat tangkap togo terdiri dari dua yaitu pelampung tanda dan pelampung utama.
Pelampung tanda terbuat dari jerigen (jerry can) bekas minyak yang berbentuk kotak. Pelampung utama berjumlah 4-7 buah terbuat dari bahan plastik yang dipasang pada bagian tali ris atas berfungsi sebagai daya apung dalam membuka bagian mulut sayap saat pengoperasian alat tangkap berlangsung. Pemberat terbuat dari timah dengan ukuran 40 gram yang dirangkai pada bagian tali ris bawah dengan jarak 20 $\mathrm{cm}$ antar pemberat. Perahu yang digunakan ialah perahu tradisional bermotor dan hanya digunakan sebagai alat transportasi. Perahu yang dikenal sebagai jukung ini memiliki panjang 6 meter, lebar 1 meter dan tinggi 30 $\mathrm{cm}$. Jenis kayu yang digunakan seperti jani dan lanan.

Saat pengoperasian di sungai, jaring togo dihubungkan dengan tiang utama yang ditancapkan ke tanah. Pada kanan dan kiri mulut jaring dipasang gelang-gelang dari rotan yang diikat pada galah pengangkat untuk memudahkan pengangkatan dan penurunan jaring pada waktu dioperasikan, sedangkan mulut jaring merupakan pintu tempat udang atau ikan masuk. Tinggi galah pengangkat disesuaikan dengan kedalaman perairan, tetapi umumnya disamakan dengan kedalaman perairan pada saat pasang tertinggi.

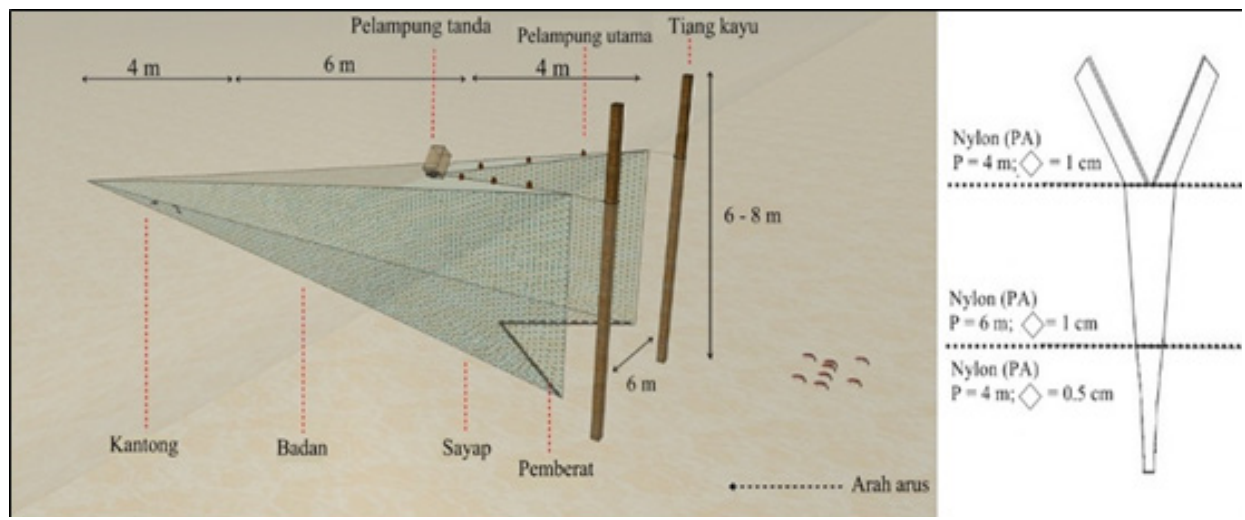

Gambar 1. Ilustrasi alat tangkap togo yang dioperasikan di sungai

Unit penangkapan ikan togo yang dioperasikan di tambak

Alat tangkap togo yang dioperasikan di tambak hampir menyerupai togo di sungai. Kontruksi togo sangat sederhana dan hanya terdiri dari kantong. Kantong terbuat dari nylon berwarna biru tua, dengan ukuran mesh size adalah $1 \mathrm{~cm}$. Panjang jaring sekitar 5 meter, lebar jaring atas 3 meter dan semakin ke bawah ukuran lebar semakin mengecil. Mulut sungkur berbentuk segi empat yang terbuat dari bingkai kayu dengan panjang 2 meter dan lebar antar dua kayu adalah 1 meter yang disesuaikan dengan ukuran pintu tambak. Jenis kayu yang digunakan adalah ulin atau besi dengan diameter kayu kira-kira $7 \mathrm{~cm}$.

Tambak merupakan bagian utama dari seperangkat alat tangkap ini. Fungsi tambak adalah sebagai penampungan sementara sebelum ikan atau gerombolan ikan ditangkap menggunakan togo. Terdapat dua macam tambak yaitu tambak yang dibuat pemerintah dan tambak yang dibuat masyarakat. Tambak yang dibuat pemerintah dibuat menggunakan teknologi 
maju dengan ekskavator, dengan luas lahan tambak seluas 4 ha. Tambak buatan masyarakat dibuat hanya menggunakan alat sederhana seperti cangkul, linggis, parang dan lainnya dengan ukuran tambak bervariasi antara 4-10 ha. Kedalaman tambak umumnya 1.5 meter dengan kedalaman di pintu masuk sekitar 1 meter. Pintu masuk bertujuan untuk membantu mengarahkan air dan ikan masuk ke dalam atau ke luar tambak. Tinggi rendahnya mulut togo disesuaikan dengan kedalaman pintu masuk tambak sehingga udang tidak dapat meloloskan diri ketika pemanenan. Kondisi tambak di desa Cemara Labat umumnya masih ditumbuhi satu hingga dua pohon mangrove yang bertujuan untuk menciptakan lingkungan yang disukai oleh udang terutama udang kecil (Gambar 2).

Pondok berfungsi sebagai tempat menunggu hingga proses penangkapan hasil selesai dilakukan. Ukuran pondok tambak pemerintah berukuran $3 \times 3$ meter, sedangkan ukuran pondok tambak masyarakat bervariasi. Pondok tambak buatan pemerintah terbuat dari kayu yang kemudian dilapisi triplek dicat warna putih yang dilengkapi bangunan teras kecil. Pintu rumah terbuat dari kayu, sedangkan atap terbuat dari seng dengan rangka yang terbuat dari kayu. Pondok tambak buatan masyarakat terbuat dari berbagai macam jenis material di antaranya hanya terbuat dari kayu dan ada pula yang terbuat dari campuran antara kayu dan daun kelapa. Ukuran pondok tambak masyarakat juga memiliki ukuran bervariasi dengan luas rata-rata $4 \times 6$ meter. Beberapa pondok terdiri dari 2 tingkat dengan atap berbahan seng atau sirap kayu.

Umumnya nelayan berjalan kaki atau menggunakan motor untuk menuju tambak. Beberapa masyarakat dalam keadaan tertentu seperti rusaknya jalan, memanfaatkan alat transportasi perahu menuju tambak. Transportasi ini jarang dipakai dalam penggunaan sehari-hari, karena dianggap boros bahan bakar.

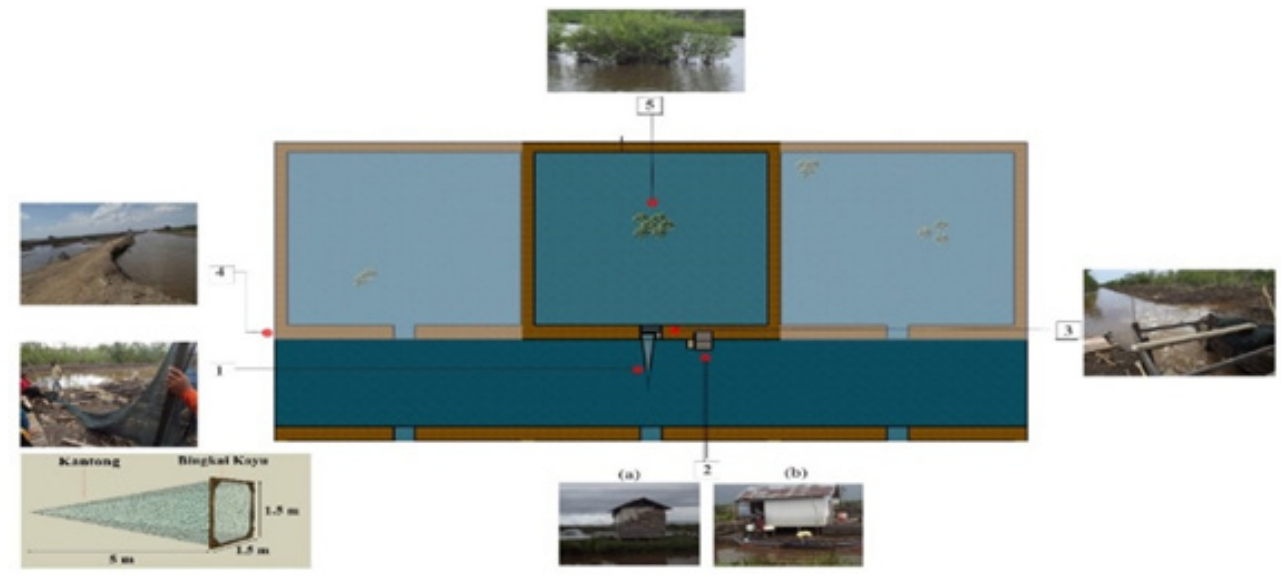

Gambar 1. Ilustrasi alat tangkap togo yang dioperasikan di sungai

Keterangan:

1. Alat tangkap togo

2. Pondok

a.Masyarakat

b.Pemerintah

3. Pintu tambak

4. Jalan setapak

5. Mangrove

\section{Pengumpulan data}

Pengumpulan data tentang tingkat tanggung jawab penggunaan alat tangkap togo menggunakan metode survei dan wawancara. Menurut Nazir (2005) metode survei adalah penyelidikan yang diadakan untuk memperoleh fakta-fakta dari gejalagejala yang ada dan mencari keterangan- keterangan secara faktual, baik tentang institusi sosial, ekonomi atau politik dari suatu kelompok ataupun suatu daerah. Penilaian tentang tingkat tanggung jawab unit penangkapan togo dapat dilakukan dengan menerapkan pendekatan multi criteria analysis sebagai perangkat pengambil keputusan yang dikembangkan untuk masalah-masalah kompleks multikriteria dalam proses pengambilan keputusan (Mendoza dan Macoun 1999). Jenis data yang dikumpulkan untuk menilai tingkat tanggung jawab ditentukan dengan menjabarkan indikator yang sesuai dengan setiap kriteria perikanan tangkap yang bertanggung jawab (Tabel 1). Penilaian tingkat tanggung jawab alat tangkap togo menggunakan metode analisis multi kriteria 
dengan 13 indikator teknologi penangkapan ikan bertanggung jawab. Berikut ini adalah tiga belas kriteria beserta indikator dan sub-indikator teknologi penangkapan ikan yang bertanggung jawab (Tabel 1).

Tabel 1. Indikator yang dikembangkan untuk menilai teknologi penangkapan ikan

\begin{tabular}{|c|c|c|c|}
\hline No & $\begin{array}{l}\text { Kriteria Perikanan } \\
\text { Bertanggung jawab }\end{array}$ & Indikator & Sub Indikator \\
\hline 1 & $\begin{array}{l}\text { Nelayan terlatih, memaha- } \\
\text { mi dan menerapkan konsep } \\
\text { efisiensi dan konservasi }\end{array}$ & $\begin{array}{c}\text { Kompetensi nelayan } \\
\left(\mathrm{X}_{1}\right)\end{array}$ & $\begin{array}{l}\text { 1. Tingkat Terlatih } \\
\text { a) Lama Pengalaman } \\
\text { Kerja } \\
\text { b) Intensitas Pelati- } \\
\text { han } \\
\text { 2. Tingkat pemaha- } \\
\text { mam dan penera- } \\
\text { pan konsep efe- } \\
\text { siensi } \\
\text { a) Paham } \\
\text { b) Penerapan } \\
\text { 3. Tingkat pemaha- } \\
\\
\text { mam dan penera- } \\
\text { pan konsep kon- } \\
\text { a) } \text { servasi } \\
\text { baham } \\
\text { b) Penerapan }\end{array}$ \\
\hline 2 & $\begin{array}{l}\text { Tidak membahayakan nelayan } \\
\text { dan orang lain di perairan }\end{array}$ & $\begin{array}{l}\text { Keselamatan di perai- } \\
\operatorname{ran}\left(\mathrm{X}_{2}\right)\end{array}$ & $\begin{array}{ll}\text { 1. Keselamatan ABK } \\
\text { 2. Keselamatan Kas } \\
\text { ko } \\
\text { 3. Keselamatan Me- } \\
\text { sin } \\
\text { 4. Keselamatan Alat } \\
\begin{array}{l}\text { Pen a n g a p a n } \\
\text { Ikan }\end{array}\end{array}$ \\
\hline 3 & Sesuai dengan peraturan & $\begin{array}{l}\text { Kepatuhan terhadap } \\
\text { peraturan }\left(\mathrm{X}_{3}\right)\end{array}$ & $\begin{array}{l}\text { 1. Jalur penangka- } \\
\text { pan } \\
\text { 2. Alat tangkap }\end{array}$ \\
\hline 4 & Hemat energi & $\begin{array}{l}\text { Konsumsi bahan ba- } \\
\text { kar kapal }\left(\mathrm{X}_{4}\right)\end{array}$ & 1. Jumlah bahan \\
\hline 5 & Tidak menghasilkan polusi & & $\begin{array}{l}\text { ai } \\
\text { Penggunaan an- } \\
\text { gin sebagai tena- } \\
\text { ga penggerak ka- } \\
\text { pal ikan }\end{array}$ \\
\hline 6 & $\begin{array}{l}\text { Terbuat dari bahan yang pen- } \\
\text { gadaannya tidak merusak } \\
\text { lingkungan atau ekosistem } \\
\text { yang dilindungi }\end{array}$ & $\begin{array}{l}\text { Kuantitas bahan } \\
\text { pencemar }\left(\mathrm{X}_{5}\right)\end{array}$ & $\begin{array}{l}\text { Jumlah polutan } \\
\text { udara } \\
\text { 2. Jumlah polutan } \\
\text { cair }\end{array}$ \\
\hline 7 & $\begin{array}{l}\text { Selektif: Ikan yang tertangkap } \\
\text { seragam, legal atau proper size }\end{array}$ & $\begin{array}{l}\text { Bahan pembuatan } \\
\text { alat penangkapan }\end{array}$ & $\begin{array}{l}\text { 1. Penggunaan ba- } \\
\text { han alami }\end{array}$ \\
\hline 8 & Low potential of ghost fishing & ikan $\left(\mathrm{X}_{6}\right)$ & $\begin{array}{l}\text { Penggunaan ba- } \\
\text { han buatan }\end{array}$ \\
\hline 9 & $\begin{array}{l}\text { Memanfaatkan ikan secara } \\
\text { maksimum }\end{array}$ & $\begin{array}{l}\text { Komposisi ikan yang } \\
\text { tertangkap }\left(\mathrm{X}_{7}\right)\end{array}$ & $\begin{array}{l}\text { 1. Keragaman ikan } \\
\text { yang ditangkap } \\
\text { Jumlah ikan yang } \\
\text { memiliki lega } \\
\text { atau proper size }\end{array}$ \\
\hline
\end{tabular}


Tabel 1 (lanjutan).

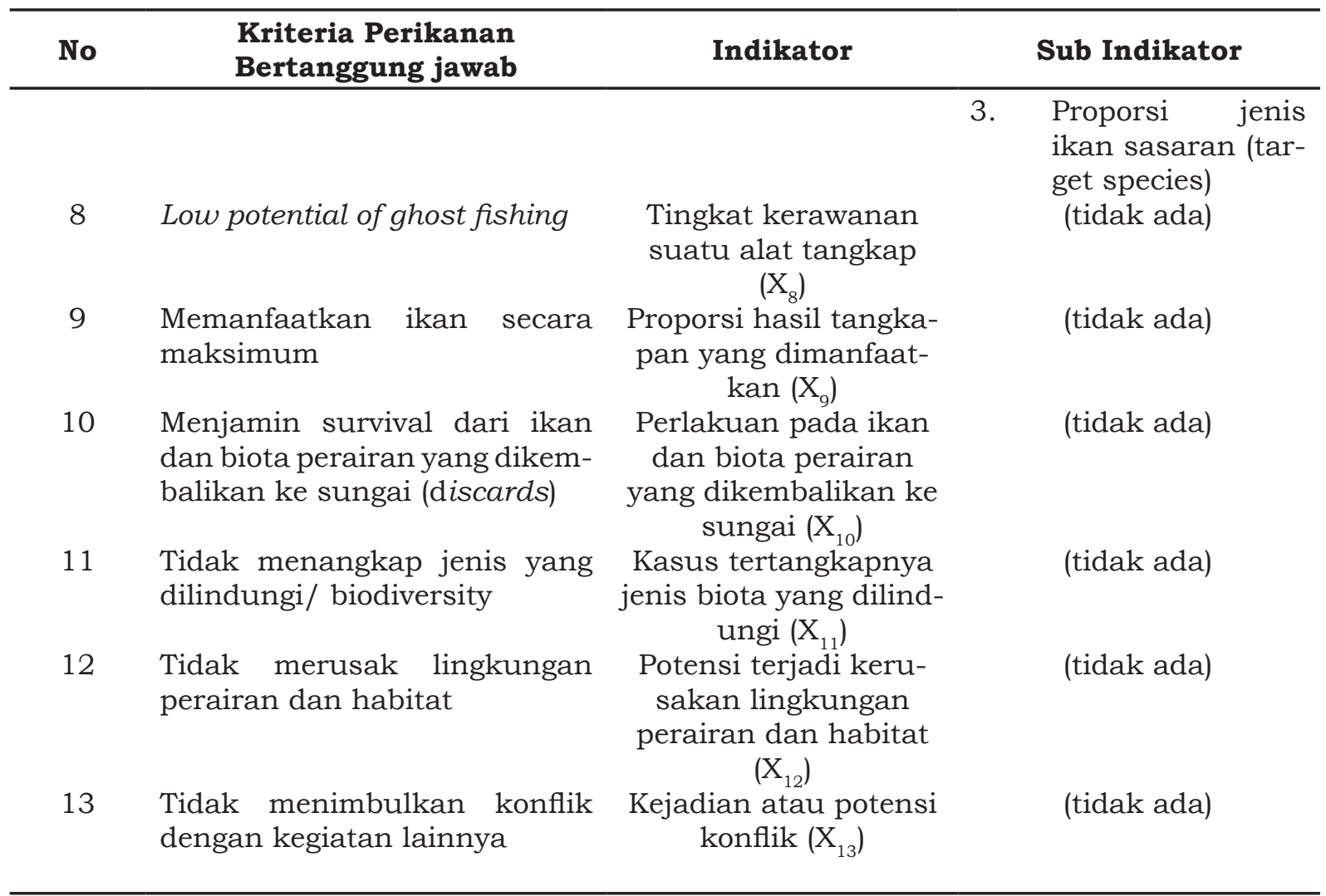

Responden dalam penelitian ini ditentukan menggunakan metode snowball sampling. Snowball sampling adalah teknik pengambilan sampel dengan bantuan keyinforman, dan dari key informan inilah akan berkembang sesuai petunjuknya. Penggunaan metode ini disebabkan sulitnya menentukan responden dari awal karena ketidaktersediaan data mengenai nelayan setempat. Peneliti pada metode ini hanya mengungkapkan kriteria sebagai persyaratan untuk dijadikan sampel (Subagyo 2006). Key informan yaitu kepala desa, selanjutnya memberikan petunjuk siapa informan yang berkompeten memberikan data. Informasi diperoleh dari responden yang memiliki pengetahuan cukup. Jumlah responden sumber informasi dibatasi masing-masing 3 orang untuk togo yang dioperasikan di sungai dan 3 orang untuk togo yang dioperasikan di tambak dan selanjutnya dinilai berdasarkan 13 kriteria perikanan bertanggung jawab.

\section{Analisis data}

Kepentingan relatif suatu kriteria terhadap keputusan yang telah dibuat harus dievaluasi dan dimasukkan ke dalam proses pengambilan keputusan untuk mendapatkan suatu pilihan. Analisis ini adalah suatu perangkat yang dapat membantu mengevaluasi tingkat kepentingan relatif selutuh kriteria yang terkait dan menggambarkan tingkat kepentingannya dalam proses pengambilan keputusanakhir(Mendozadan Macoun 1999). Penilaian tingkat tanggung jawab unit penangkapan togo menggunakan 13 indikator teknologi penangkapan ikan bertanggung jawab. Indikator yang menggunakan sub indikator, data yang diperoleh kemudian dikonversi menjadi data ordinal. Data ordinal enam responden pada tiap sub indikator dihitung rata-ratanya. Nilai rata-rata yang diperoleh tiap sub indikator kemudian dijumlahkan. Total nilai sub indikator akan menentukan kategori suatu unit penangkapan ikan; setiap kategori tersebut memiliki kriteria berupa kisaran total nilai sub indikator. Skor suatu indikator ditentukan berdasarkan kategori yang diperoleh. Berikut adalah metode penentuan skor setiap indikator. 
Indikator ke-1

$$
\begin{aligned}
& X_{2 a}=\left(\frac{n_{1_{A}}+n_{2_{A}}+n_{3_{A}}}{3}\right) \\
& x_{2 B}=\left(\frac{n_{1_{B}}+n_{2_{B}}+n_{3_{B}}}{3}\right) \\
& x_{2 C}=\left(\frac{n_{1_{C}}+n_{2_{C}}+n_{3_{C}}}{3}\right) \\
& x_{2 D}=\left(\frac{n_{1_{D}}+n_{2_{D}}+n_{3_{D}}}{3}\right) \\
& \mathrm{X}_{2}=\mathrm{x}_{2 \mathrm{~A}}+\mathrm{x}_{2 \mathrm{~B}}+\mathrm{x}_{2 \mathrm{C}}+\mathrm{x}_{2 \mathrm{D}}
\end{aligned}
$$

A adalah tingkat pelatihan, $\mathrm{B}$ adalah tingkat pemahaman dan penerapan konsep efesiensi, $\mathrm{C}$ adalah tingkat pemahaman dan penerapan konsep konservasi.

\section{Indikator ke-2}

$$
\begin{aligned}
x_{2 A}= & \left(\frac{n_{1_{A}}+n_{2_{A}}+n_{3_{A}}}{3}\right) \\
x_{2 B}= & \left(\frac{n_{1_{B}}+n_{2_{B}}+n_{3_{B}}}{3}\right) \\
x_{2 C}= & \left(\frac{n_{1_{C}}+n_{2_{C}}+n_{3_{C}}}{3}\right) \\
x_{2 D}= & \left(\frac{n_{1_{D}}+n_{2_{D}}+n_{3_{D}}}{3}\right) \\
& X_{2}=x_{2 A}+x_{2 B}+x_{2 C}+x_{2 D}
\end{aligned}
$$

A adalah keselamatan ABK, B adalah keselamatan kasko, $\mathrm{C}$ adalah keselamatan mesin, D adalah keselamatan alat penangkapan ikan.

\section{Indikator ke-3 hingga ke-6}

$$
\begin{aligned}
& x_{n A}=\left(\frac{n_{1 A}+n_{2 A}+n_{3 A}}{3}\right) \\
& x_{n B}=\left(\frac{n_{1 B}+n_{2 B}+n_{3 B}}{3}\right) \\
& X_{n}=x_{n A}+x_{n B}
\end{aligned}
$$

\section{Indikator ke-7}

$$
\begin{aligned}
& x_{7 A}=\left(\frac{n_{1_{A}}+n_{2_{A}}+n_{3_{A}}}{3}\right) \\
& x_{7 B}=\left(\frac{n_{1_{B}}+n_{2_{B}}+n_{3_{B}}}{3}\right) \\
& x_{7 C}=\left(\frac{n_{1_{C}}+n_{2_{C}}+n_{3_{C}}}{3}\right) \\
& X_{7}=x_{7 A}+x_{7 B}+x_{7 C}
\end{aligned}
$$

A adalah tingkat keseragaman, B adalah tingkat legal atau proper size, C adalah target spesies.

\section{Indikator ke-8 hingga ke-13}

$$
\begin{gathered}
x_{n}=\left(\frac{n_{1}+n_{2}+n_{3}}{3}\right) \\
X_{n}=x_{n}
\end{gathered}
$$

Indikator ke 8 s.d. 13 tidak memiliki sub-indikator.

Total Skor (YS) $=\mathrm{X}_{1}+\mathrm{X}_{2}+\mathrm{X}_{3}+\ldots \ldots+\mathrm{X}_{13}$

Keterangan:

$$
\begin{array}{ll}
\mathrm{n} & \text { : Nelayan atau responden } \\
\mathrm{x} & \text { : Sub indikator } \\
\mathrm{X} & \text { : Indikator }
\end{array}
$$

Tiap indikator terdiri dari 3 nilai yaitu 1, 2 dan 3; nilai 3 berarti baik, nilai 2 berarti tergolong cukup dan nilai 1 tergolong tidak baik. Semakin tinggi skor suatu indikator berarti unit penangkapan ikan memiliki ciri yang semakin mendekati suatu kriteria ideal. Penentuan unit penangkapan terbaik dilakukan berdasarkan nilai total skor tertinggi.

Strategi perbaikan unit penangkapan ikan dikembangkan berdasarkan penilaian kinerja pada status teknologi penangkapan ikan dan kelayakan usaha untuk memperbaiki indikator yang bernilai rendah. Strategi ini merupakan rekomendasi perbaikan yang difokuskan pada indikatorindikator terburuk sehingga unit penangkapan ikan tersebut akan semakin memenuhi kriteria ideal bertanggung jawab.

\section{HASIL DAN PEMBAHASAN}

\section{Status teknologi penangkapan ikan togo}

Masalah yang sering timbul pada kedua togo ialah adanya pendapat masyarakat mengenai sumberdaya milik umum dan milik bersama. Karena itu, lahir banyak pemikiran bahwa selama sumberdaya alam masih dalam keadaan baik harus dieksploitasi sebanyak mungkin (Nadeak 2009). Hal ini mengakibatkan penggunaan sumberdaya alam secara berlebihan, atau menghabiskan sumberdaya alam secara cepat, bahkan dapat menghancurkan sumberdaya alam baik yang dapat diperbaharui (renewable 
resources).

Banyak kasus penggunaan sumberdaya alam milik umum yang tidak memperhatikan konsepsi keseimbangan. Jika hal ini terjadi maka sumberdaya perikanan togo akan habis dan mengancamkelestarian ekologi serta ekosistem yang ada di wilayah tersebut yang kemudian berdampak pada pertumbuhan ekonomi. Oleh karena itu, untuk menjaga kelestarian sumberdaya ikan perlu dikaji penggunaan unit penangkapan ikan yang bertanggung jawab dari segi pengoperasian alat penangkapan ikan, daerah penangkapan dan lain sebagainya sesuai dengan tata laksana untuk perikanan yang bertanggungjawab atau Code of Conduct for Responsible Fisheries (CCRF).

Penilaian teknologi penangkapan ikan dilakukan untuk mewujudkan perikanan tangkap yang semakin bertanggung jawab. Pengolahan data menghasilkan sebuah nilai yang menentukan kategori setiap kriterianya. Nilai dari setiap indikator di sungai dan tambak merupakan rata-rata dari tiga nelayan di sungai dan tiga nelayan di tambak (Tabel 2).

Tabel 2. Skor setiap indikator unit penangkapan ikan

\begin{tabular}{ccc}
\hline & \multicolumn{2}{c}{ Unit Penangkapan Ikan } \\
\cline { 2 - 3 } Indikator & $\mathbf{Y}_{\mathbf{1}}$ & $\mathbf{Y}_{\mathbf{2}}$ \\
\cline { 2 - 3 } $\mathrm{X}_{1}$ & 2 & 2 \\
$\mathrm{X}_{2}$ & 2 & 3 \\
$\mathrm{X}_{3}$ & 2 & 3 \\
$\mathrm{X}_{4}$ & 2 & 3 \\
$\mathrm{X}_{5}$ & 3 & 3 \\
$\mathrm{X}_{6}$ & 3 & 3 \\
$\mathrm{X}_{7}$ & 3 & 3 \\
$\mathrm{X}_{8}$ & 3 & 3 \\
$\mathrm{X}_{9}$ & 3 & 2 \\
$\mathrm{X}_{10}$ & 1 & 1 \\
$\mathrm{X}_{11}$ & 3 & 3 \\
$\mathrm{X}_{12}$ & 3 & 2 \\
$\mathrm{X}_{13}$ & 3 & 2 \\
TOTAL & $\mathbf{3 3}$ & $\mathbf{3 3}$ \\
\hline
\end{tabular}

\section{Keterangan:}

$\mathrm{Y}_{1}$ : Togo yang dioperasikan di sungai; $\mathrm{Y}_{2}$ : Togo yang dioperasikan di tambak

Kompetensi nelayan $\left(\mathrm{X}_{1}\right)$; Keselamatan di perairan $\left(\mathrm{X}_{2}\right)$; Kepatuhan terhadap peraturan $\left(\mathrm{X}_{3}\right)$; Konsumsi bahan bakar kapal $\left(\mathrm{X}_{4}\right)$; Kuantitas bahan pencemar $\left(\mathrm{X}_{5}\right)$; Bahan pembuatan alat penangkapan ikan $\left(\mathrm{X}_{6}\right)$; Komposisi ikan yang tertangkap $\left(\mathrm{X}_{7}\right)$; Tingkat kerawanan suatu alat tangkap $\left(\mathrm{X}_{8}\right)$; Proporsi hasil tangkapan yang dimanfaatkan $\left(\mathrm{X}_{9}\right)$; Perlakuan pada ikan dan biota perairan yang dikembalikan ke perairan $\left(\mathrm{X}_{10}\right)$; Kasus tertangkapnya jenis biota yang dilindungi $\left(\mathrm{X}_{11}\right)$; Potensi terjadi kerusakan lingkungan perairan dan habitat $\left(\mathrm{X}_{12}\right)$; dan Kejadian atau potensi konflik $\left(\mathrm{X}_{13}\right)$.

Berdasarkan Tabel 2 diketahui indikator ke-1 $\left(\mathrm{X}_{1}\right)$ menunjukkan unit penangkapan togo di sungai maupun di tambak telah dioperasikan oleh nelayan yang cukup terlatih, memahami dan menerapkan konsep efisiensi dan konservasi (skor 2). Sebagian besar nelayan togo di sungai di Kabupaten Kapuas memiliki pengalaman kerja rata-rata lebih dari 5 tahun sementara togo di tambak berkisar 2-5 tahun. Nelayan kedua jenis togo juga menunjukkan minat yang cukup tinggi dalam mengikuti program pelatihan yang diselenggarakan oleh pemerintah diantaranya pembinaan dan pengembangan metode penangkapan dan pelatihan mengenai penanganan hasil tangkapan. Kurangnya pemahaman tentang konsep efesiensi dan konservasi juga merupakan suatu hambatan dalam melaksanakan pengelolaan perikanan secara bertanggung jawab. Aspek-aspek pada indikator ke-2 $\left(\mathrm{X}_{2}\right)$ menunjukkan unit penangkapan togo di sungai agak membahayakan nelayan dan orang lain di perairan sungai, sementara itu togo yang dioperasikan di tambak termasuk 
tidak membahayakan nelayan dan orang lain karena lokasi tempat penangkapan sudah tetap dan memiliki jalur yang pasti. Unit penangkapan ikan togo di sungai yang diteliti tidak menyediakan fasilitas keselamatan di atas kapal. Tampaknya hal ini disebabkan pola pikir nelayan tentang kurang pentingnya kelengkapan fasilitas keselamatan dikarenakan hampir setiap nelayan di Desa Cemara Labat memiliki kemampuan renang walaupun belum ada pembuktian lebih lanjut. Pengabaian terhadap fasilitas keselamatan perlu menjadi perhatian sebab lingkungan kerja di atas air memiliki risiko tinggi mengingat kecelakaan sungai dapat terjadi sewaktu-waktu atau tak terduga.

Berdasarkan sub indikator jalur penangkapan pada indikator ke-3 $\left(\mathrm{X}_{3}\right)$, seluruh unit penangkapan ikan selalu dioperasikan pada jalur penangkapan. Sementara itu, sub indikator kesesuaian alat tangkap pada togo yang dioperasikan di sungai tergolong agak sesuai yang disebabkan alat tangkap ini merupakan modifikasi dari alat tangkap sungkur namun tetap berfungsi untuk menangkap udang dan ikan. Kekurangsesuaian alat tangkap tidak menjadi hambatan dikarenakan pemanfaatannya masih sesuai dengan tujuan hasil tangkapannya yaitu udangudangan.

Peneliti tidak dapat melakukan pengukuran secara kuantitatif pada indikator ke-4 $\left(\mathrm{X}_{4}\right)$ disebabkan penggunaan bahan bakar di Kabupaten Kapuas yang merupakan minyak campuran, sehingga peneliti hanya melakukan pengamatan terhadap unit penangkapan ikan togo yang dioperasikan di sungai berdasarkan jumlah bahan bakar serta campuran bahan bakar yang digunakan. Unit penangkapan togo yang dioperasikan di tambak tidak di amati berdasarkan indikator ini, disebabkan dalam kegiatan pengoperasiannya, pada umumnya nelayan berjalan kaki atau menggunakan motor menuju lokasi penangkapan (tambak). Melanjuti indikator sebelumnya (indikator ke-4), kuantitas bahan pencemar yang digunakan togo yang dioperasikan di sungai menghasilkan polusi yang rendah, sedangkan togo yang dioperasikan di tambak tidak dilakukan pengamatan. Hasil yang diperoleh pada sub indikator polusi cair adalah seluruh teknologi penangkapan ikan berada pada skor 3 yaitu terjadi pencemaran air yang rendah di perairan. Berdasarkan umur mesin penggerak kapal, dapat diasumsikan bahwa semakin tua mesin kapal dan semakin besar jarak tempuh berarti semakin tinggi polusi yang disumbangkan ke lingkungan jika servis tidak dilakukan secara rutin.

Dilihat dari hasil indikator ke-6 $\left(\mathrm{X}_{6}\right)$, penggunaan jumlah bahan alami pada kedua unit togo seperti tongkat kayu pada togo dianggap tidak merusak. Indikator ke-7 $\left(\mathrm{X}_{7}\right) \quad$ menunjukkan udang yang tertangkap oleh togo yang dioperasikan di sungai cukup seragam, legal atau proper size. Tingkat keseragaman jenis udang cukup berbeda walaupun masih termasuk udang-udangan yaitu udang pici, udang rebon, udang lampis dan udang bajang. Togo yang dioperasikan di tambak tergolong seragam, legal atau proper size dengan hasil tangkapan yang didominasi udang pici. Tingkat keseragaman dan kelegalan erat kaitannya dalam menjaga kelestarian sumberdaya secara berkelanjutan.

Penilaian pada indikator ke-8 $\left(\mathrm{X}_{8}\right)$ menunjukkan alat tangkap togo yang dioperasikan di sungai Cemara Labat tidak memiliki potensi terjadinya "ghost fishing" karena dalam pengoperasian alat tangkap di set di perairan dengan kedalaman yang rendah serta dalam pengoperasiannya hanya dibiarkan dalam waktu tertentu (3-5 jam) dalam sungai. Hal ini juga berlaku untuk togo yang dioperasikan di tambak yang tidak memiliki potensi terjadinya "ghost fishing" karena alat tangkap telah di set di tambak yang memiliki posisi yang tetap.

Unit penangkapan ikan togo pada indikator ke-9 $\left(\mathrm{X}_{9}\right)$ yang di sungai memanfaatkan hasil tangkapan secara maksimum, sedangkan togo di tambak hanya tergolong cukup. Penggunaan akodan sebagai bahan pembersih lahan tambak untuk menjaga kelangsungan hidup udang menyebabkan banyak ikan terutama ikan sungai dan ikan laut yang dianggap sebagai predator mati dan mengambang di perairan tambak diantaranya betok dan patin. Kurang dimanfaatkannya ikan sehingga setelah mati biasanya ikan dibiarkan mengembang perairan hingga membusuk dan mengendap 
disungai yang kemudian dianggap menjadi sumber pakan tambahan bagi udang (tidak ada pembuktian secara ilimiah).

Indikator ke-10 ( $\left.\mathrm{X}_{10}\right)$ menunjukkan ikan dan biota perairan yang tidak layak tangkap dikembalikan ke sungai tidak dijamin keberlangsungan hidupnya oleh seluruh unit penangkapan ikan. Nelayan di wilayah perairan ini memiliki pandangan yang sama mengenai keberlangsungan hidup ikan. Alasan tidak dijaminnya hidup ikan adalah karena hampir sebagian besar hasil tangkapan yang tertangkap mati setelah didaratkan. Kurangnya informasi mengenai pentingnya menjaga kelangsungan hidup ikan menyebabkan kurang dihargainya biota perairan.

Seluruh unit penangkapan ikan dalam pengoperasiannya tidak pernah menangkap jenis biota yang dilindungi/biodiversity pada indikator ke-11 $\left(\mathrm{X}_{11}\right)$. Jenis yang dilindungi pada perairan sungai di Kabupaten Kapuas ialah arwana (Scleropages formosus) dan labi-labi (Pelodiscus sinensis).

Indikator ke-12 $\left(\mathrm{X}_{12}\right)$ menunjukkan metode dan operasi penangkapan ikan pada alat tangkap togo di sungai tergolong tidak merusak lingkungan perairan dan habitat. Beda halnya dengan togo yang dioperasikan di tambak yang tergolong cukup merusak lingkungan perairan dan habitat terutama kawasan mangrove. Penebangan pohon mangrove untuk pembuatan lahan tambak cukup berdampak terhadap produksi udang yaitu hilangnya sumber protein udang walaupun dalam satu tambak masih tersisa 1 hingga 3 pohon yang tidak ditebang.

Unit penangkapan ikan togo yang dioperasikan di sungai pada indikator ke$13\left(\mathrm{X}_{13}\right)$ menunjukkan tidak timbulnya konflik dengan kegiatan lainnya, sedangkan togo yang di tambak termasuk cukup menimbulkan konflik dengan kegiatan lainnya dikarenakan tidak meratanya kepemililikan tambak disebabkan modal investasi yang cukup besar sehingga walaupun ada program pemerintah namun tidak sedikit masyarakat yang tidak tahu dan merasa tidak mendapatkan kesempatan untuk bekerja pada bagian ini. Konflik kecil yang tejadi tetap perlu diwaspadai agar tidak menjadi besar kedepannya, sehingga perlu kejelasan dari pemerintah mengenai program ini agar seluruh masyarakat tahu dan dapat berpatisipasi dalam rangka meningkatkan perekonomian keluarga.

Berdasarkan hasil analisis Tabel 2, kedua togo memiliki skor yang sama yaitu 33 yang berarti kedua unit penangkapan memiliki kekurangan dan kelebihan masingmasing yang kedepannya dapat diperbaiki untuk memajukan perikanan di Desa Cemara Labat. Kedua unit penangkapan memiliki skor terendah yaitu 1 (buruk) pada indikator menjamin survival dari ikan dan biota perairan yang dikembalikan di perairan $\left(\mathrm{X}_{10}\right)$ dan 2 (cukup baik) pada indikator kompetensi nelayan $\left(\mathrm{X}_{1}\right)$. Adapun indikator dengan nilai skor 2 pada unit penangkapan togo yang dioperasikan di sungai yaitu indikator keselamatan di perairan $\left(\mathrm{X}_{2}\right)$, kepatuhan terhadap peraturan $\left(\mathrm{X}_{3}\right)$ dan konsumsi bahan bakar kapal $\left(\mathrm{X}_{4}\right)$ yang memiliki skor 2, dari tiga skor ini pembahasan akan difokuskan pada indikator $\mathrm{X}_{2}$. Togo yang dioperasikan di tambak yang memiliki skor 2 lainnya yaitu indikator proporsi hasil tangkapan yang dimanfaatkan $\left(\mathrm{X}_{9}\right)$, potensi terjadi kerusakan lingkungan perairan dan habitat $\left(\mathrm{X}_{12}\right)$ dan kejadian atau potensi $\operatorname{konflik}\left(\mathrm{X}_{13}\right)$, dari tiga indikator ini pembahasan akan difokuskan pada indikator $\mathrm{X}_{12}$. Kedua jenis unit penangkapan ikan yang diteliti memiliki masalah untuk indikator perlakuan pada ikan dan biota perairan yang dikembalikan ke sungai $\left(\mathrm{X}_{10}\right)$. Nelayan di Desa Cemara Labat menganggap persoalan discard bukan persoalan penting karena perhatian mereka lebih kepada jenisjenisikanyangmenjadisasaran penangkapan ikan, serta mengingat sulit menjamin ikan tetap hidup setelah didaratkan. Meskipun jumlah discards rendah karena sebagian besar hasil tangkapan dimanfaatkan $\left(\mathrm{X}_{9}\right)$, jika ikan-ikan tersebut sebagian besar masuk dalam kategori tidak layak tangkap, maka ancaman terjadinya overfishing juga tetap ada. Overfishing dapat menyebabkan berkurang atau musnahnya salah satu alur jaring makanan yang berdampaknya hilangnya sumber makanan bagi spesies tertentu. Terganggunya ketersediaan mangsa dan juga proporsi predator akan menyebabkan terganggunya keseimbangan pada jaring makanan (food web) terutama 
ekosistem perairan secara keseluruhan.

Kompetensi nelayan togo di sungai dan di pasar juga terbilang cukup baik (skor 2), dengan hasil skor nelayan di sungai 13.3 lebih tinggi dibandingkan di tambak 11.7. Tingkat pemahaman dan penerapan konsep konservasi nelayan kedua unit penangkapan termasuk kategori rendah. Hal ini menjadi perhatian lebih terutama untuk perikanan di tambak yang berkaitan dengan kawasan mangrove. Pandangan nelayan mengenai pemanfaatan hutan mangrove sangat penting, sehingga peningkatan pengetahuan diperlukan dengan semakin tingginya tingkat pengetahuan masyarakat terkhususnya nelayan tentang hutan mangrove di daerah ini, semakin tinggi persepsinya terhadap keberadaan hutan mangrove (Ritohardoyo et al. 2011).

Perikanan togo di sungai memiliki 3 indikator lain yang bernilai cukup baik (skor 2) yang mana dari ketiga indikator, indikator keselamatan di sungai cukup menarik perhatian. Meskipun transportasi yang digunakan hanya perahu dan jalur penangkapan di sungai dengan kedalaman $<7$ meter, peranan keselamatan dan perlunya perangkat keselamatan di atas perahu merupakan hal yang mutlak dipertimbangkan karena menyangkut nyawa orang yang berada di atas perahu. Keberadaan perangkat keselamatan pada kapal atau perahu perikanan didasarkan ukuran perahu terutama berkaitan dengan jumlah, ukuran, dan kesesuaian perangkat tersebut. Keberadaan dan penggunaan perlengkapan keselamatan kerja yang sesuai dengan standar alat-alat keselamatan yang wajib dimiliki dan disediakan di atas kapal sesuai Safety of Life at Sea (SOLAS) '74 dapat memperkecil risiko kecelakaan dini maupun kecelakaan yang telah terjadi, sehingga dapat terhindar dari akibat fatal yang tidak diinginkan (Santara et al 2014). Salah satu contohnya ialah terjadi kram ketika terjatuh di sungai. Meskipun nelayan beranggapan bahwa mereka dapat berenang, namun jika dalam kondisi seperti itu nelayan dapat mengandalkan life jacket sebagai pengatur daya apung pengguna agar dapat berada pada posisi melayang di dalam air.
Perikanan togo di tambak juga memiliki 3 indikator tambahan bernilai cukup baik (skor 2) yang mana indikator potensi yang cukup merusak lingkungan $\left(\mathrm{X}_{12}\right)$ yaitu kawasan mangrove cukup menarik perhatian. Kehidupan biota perairan dan lingkungan saling tergantung satu sama lain, lingkungan yang buruk akan mengganggu yang merupakan habitat bagi sejumlah besar organisme akuatik (ikan, moluska, burung, serangga, tanaman air dan sebagainya) dan mendukung keanekaragaman hayati pada wilayah daratan dan sekelilingnya, termasuk sejumlah burung migrasi (Sukimin 2007).

Kondisi tambak di Desa Cemara Labat sebenarnya masih bagus dan sebagian besar tambak masih ditanami sedikit mangrove yang dapat menopang kebutuhan protein udang. Mangrove mengangkut unsur hara dan detritus ke perairan pesisir sehingga produksi primer perairan di sekitar mangrove cukup tinggi dan penting bagi kesuburan perairan. Serasah daun, ranting, bunga, dan buah dari tumbuhan mangrove dimanfaatkan oleh makrofauna, misalnya kepiting kemudian didekomposisi oleh berbagai jenis mikroba yang melekat di dasar perairan dan secara bersamasama membentuk rantai makanan. Detritus selanjutnya dimanfaatkan oleh hewan akuatik yang mempunyai tingkat lebih tinggi seperti bivalvia, gastropoda, berbagai jenis ikan juvenil dan udang, serta kepiting (Gunarto 2004). Penggunaan tambak di Desa Cemara Labat memang merupakan hal baru terhitung sejak tahun 2005, namun tidak dengan kasus di Sulawesi Selatan. Lahan tambak di Sulawesi Selatan sebagai pengguna sebelum nelayan Desa Cemara Labat pada awalnya sangat bagus untuk sumber penghasilan tambahan masyarakat, namun karena pembukaan lahan tambak yang semakin marak sehingga menimbulkan konflik yang serius. Pola tradisional itu mulai berubah menjadi tambak intensif yang menggunakan pupuk sejak tahun 1980-an yang diperkenalkan oleh para pengusaha pendatang dari Jawa. Sejak saat itu, pertambakan di pesisir ini menjadi sangat 
tergantung pada pupuk. Lingkungan tidak sanggup lagi menghasilkan nutrisi untuk ikan karena mangrovenya rusak. Akibatnya produksi tambak makin turun dari tahun ke tahun, padahal biaya produksinya terus meningkat. Hal inilah yang mengakibatkan banyaknya lahan tambak yang terlantar. Bahkan sebagian kecil lahan tambak sudah dialihfungsikan menjadi lahan pertanian dan perumahan.

Potensi perikanan kedua jenis togo di Desa Cemara Labat hingga saat ini dalam kategori cukup baik dan dapat memberikan manfaat yang lebih maksimal secara berkelanjutan bagi nelayan di Desa Cemara Labat, bila dikelola dengan baik dan bertanggungjawab. Oleh karena itu, menghindari terjadi kasus yang sama di Desa Cemara Labat, strategi perbaikan pada perikanan tangkap togo sangat diperlukan dalam upaya menjaga sumberdaya dan ekosistem lingkungan perikanan togo di tambak maupun sungai secara optimal dan lestari.

\section{Strategi perbaikan perikanan tangkap}

Pengelolaan sumberdaya perikanan merupakan suatu sistem yang sangat kompleks. Keberlanjutan merupakan kata kunci dalam pembangunan perikanan yang diharapkan dapat memperbaiki sumber daya dan masyarakat perikanan itu sendiri. Pengembangan penangkapan ikan pada hakikatnya mengarah ke pemanfaatan sumber daya ikan secara optimal dan rasional bagi kesejahteraan masyarakat pada umumnya dan nelayan khususnya, tanpa menimbulkan kerusakan sumber daya ikan itu sendiri maupun lingkungannya (Rosalina 2011). Strategi perbaikan perikanan tangkap yang dapat dilakukan antara lain penekanan pada karakteristik dan perilaku nelayan melalui sosialisasi dan pembatasan jumlah tambak dan togo di Desa Cemara Labat.

Penekanan pada karakteristik dan perilaku sosial ekonomi nelayan sangat penting sebagai langkah awal strategi. Strategi dilakukan secara internal dari dalam diri nelayan, yang bisa juga disebut strategi inovasi sosial (Hamzens dan Sumardjo 2007) melalui pemberian penyuluhan untuk meningkatkan kompetensi nelayan. Materi penyuluhan yang diberikan mencakup pentingnya keselamatan selama kegiatan penangkapan, peningkatan konsep efesiensi dan konservasi. Konsep efesiensi perikanan yang dimaksudkan ialah penggunaan dan pemanfaatan sumberdaya perikanan yang berada di perairan untuk pencapaian hasil yang optimum, sedangkan konsep konservasi adalah konsep konservasi perairan secara keseluruhan yang dalam pemanfaatannya dapat menjaga dan memelihara seluruh fungsi hingga dapat lestari pada waktu yang akan datang.

Prinsip yang harus diperhatikan dalam pemberian penyuluhan yaitu tanggap, akurat, transparan, efisien dan efektif. Bentuk pelaksanaan pengawasan adalah monitoring dan evaluasi partisipatif, sedangkan teknik dapat berupa curah pendapat, tanya jawab, diskusi kelompok, diskusi pleno, peragaan, forum pengaduan masyarakat dan penyelesaian masalah (Rachman 2012). Program penyuluhan dapat diberikan secara berkala dan diharapkan menjadi sebuah program jangka panjang, karena kondisi setiap waktu dapat berubah dan akan terus berkembang seiring dengan perubahan dan perkembangan zaman.

Permasalahan selanjutnya yang harus diperhatikan ialah pengalihan fungsi lahan hutan mangrove. Sebagai sarana untuk mencapai keseimbangan pemenuhan kebutuhan bagi generasi sekarang maupun generasi yang akan datang, pelaksanaan pembangunan perikanan harus berwawasan lingkungan, walaupun pada praktiknya masih terdapat satu atau dua buah pohon mangrove dalam setiap tambak. Pengalihan fungsi lahan hutan mangrove ini tidak boleh diabaikan mengingat ada dua alasan pentingnya mempertahankan mangrove di Desa Cemara Labat, antara lain :

1. Hutan mangrove menyumbangkan konstribusi besar detritus organik yang mendukung jaring makanan dalam ekosistem.

2. Hilangnya mangrove memberi efek dratis berupa terjadinya banjir dan erosi pantai yang mengakibatkan penurunan hasil perikanan (Wardhani 2011). 
Pemanfaatan sumberdaya mangrove yang tidak didasarkan kepentingan ekologis pada kenyataannya akan dapat mengancam kapasitas berkelanjutan ekosistem.

Pembangunan juga harus berorientasi kepada kesejahteraan, yaitu suatu strategi pembangunan yang dibangun dengan titik berat kesejahteraan masyarakat dan tidak sebagai peningkatan produksi (Tambunan et al. 2005). Bertambahnya jumlah tambak yang diiringi dengan pertambahan nelayan tambak juga dikhawatirkan dapat menimbulkan konflik baru antar nelayan karena tingkat persaingan yang akan menjadi semakin tinggi sehingga hasil tangkapan yang diperoleh juga semakin berkurang. Oleh karena itu, berdasarkan pertimbangan tersebut, perlu pembatasan jumlah tambak di Desa Cemara Labat sebagai salah satu langkah dalam pengelolaan ekosistem mangrove dan tambak secara optimal dan berkelanjutan. Hal ini juga berlaku untuk penangkapan togo di sungai, sehingga diharapkan nelayan togo yang di sungai dan tambak dapat memperoleh jumlah hasil tangkapan yang optimal.

Perencanaan seluruh kegiatan harus melewati pengawasan dan dilaksanakan sesegera mungkin. Oleh karena itu, agar pengelolaan perikanan dapat berjalan dengan baik serta untuk menghindari konflik dalam masyarakat, maka perlu menjalin koordinasi dengan semua pihak yang terkait.

\section{KESIMPULAN DAN SARAN}

Kedua togo tergolong buruk (skor 1) pada indikator menjamin survival dari ikan dan biota perairan yang dikembalikan di sungai $\left(\mathrm{X}_{10}\right)$ dan cukup baik (skor 2) pada indikator kompetensi nelayan $\left(\mathrm{X}_{1}\right)$. Indikator yang berstatus cukup baik (skor 2) lainnya pada unit penangkapan togo yang dioperasikan di sungai yaitu keselamatan di sungai $\left(\mathrm{X}_{2}\right)$, kepatuhan terhadap peraturan
$\left(\mathrm{X}_{3}\right)$ dan konsumsi bahan bakar kapal $\left(\mathrm{X}_{4}\right)$, sedangkan untuk togo yang dioperasikan di tambak yaitu indikator proporsi hasil tangkapan yang dimanfaatkan $\left(\mathrm{X}_{\mathrm{q}}\right)$, potensi terjadi kerusakan lingkungan perairan dan habitat $\left(\mathrm{X}_{12}\right)$ dan kejadian atau potensi onflik $\left(\mathrm{X}_{13}\right)$. Strategi perbaikan perikanan tangkapantara lain penekanan pada karakteristik dan perilaku nelayan melalui sosialisasi dan pembatasan jumlah tambak dan togo di Desa Cemara Labat.

\section{DAFTAR PUSTAKA}

Brown SK, Auster PJ, Lauck L, Coyne M. 1998. Ecological effects of fishing. national oceanic and atmospheric administration (NOAA) NOAA's state of the coast report. Silver Spring, MD: NOAA.

Gunarto. 2004. Konservasi mangrove sebagai pendukung sumber hayati perikanan pantai. J. Litbang Pertanian. 23(1):1521.

Hamzens WPS, Sumardjo. 2007. Strategi inovasi sosial pengembangan mutu sumber daya manusia nelayan. $J$. Penyuluhan. 3(1):1-10.

Mendoza GA, Macoun P. 1999. Panduan untuk menerapkan analisis multi kriteria dalam menilai kriteria dan indikator. Bogor: SMK Grafika Mardi Yuana.

Nadeak A. 2009. Kawasan basis sektor perikanan dan kelautan. $J$. Perencanaan dan pengembangan wilayah. 4(3):102-110.

Rahman M. 2012. Konservasi nilai dan warisan budaya. J. of Conservation. $1(1): 30-39$.

Ritohardoyo S, Ardi GB. 2011. Arahan kebijakan pengelolaan hutan mangrove: Kasus pesisir kecamatan Teluk Pakedai, Kabupaten Kubu Raya, Propinsi Kalimantan Barat. $J$. Geografi. 8(2):83-94. 
Rosalina D. 2011. Analisis strategi pengembangan perikanan pelagis di Kabupaten Banyuasin Provinsi Sumatera Selatan. J. Kebijakan Sosial Ekonomi Kelautan dan Perikanan. 1(1):63-77.

Santara AG, Purwangka F, Iskandar BH. 2014. Peralatan keselamatan kerja pada perahu slerek di PPN Pengambengan, Kabupaten Jembrana, Bali. J. Ipteks PSP. 1(1):53-68.

Sukimin S. 2007. Penggunaan index of biotic integrity (IBI) untuk menilai kualitas lingkungan perairan. $J$. Teknik Lingkungan. 8(1):84-90. 